\title{
Cytotoxic Effects of Newly Synthesized Palladium(II) Complexes of Diethyldithiocarbamate on Gastrointestinal Cancer Cell Lines
}

\author{
Shahram Hadizadeh, ${ }^{1}$ Nowruz Najafzadeh, ${ }^{2}$ Mohammad Mazani, ${ }^{1}$ Mojtaba Amani, \\ Hassan Mansouri-Torshizi, ${ }^{4}$ and Ali Niapour ${ }^{2}$ \\ ${ }^{1}$ Department of Biochemistry, School of Medicine, Ardabil University of Medical Sciences, Ardabil 5618985991, Iran \\ ${ }^{2}$ Laboratory of Embryology and Stem Cells, Department of Anatomy and Pathology, School of Medicine, \\ Ardabil University of Medical Sciences, Ardabil 5618985991, Iran \\ ${ }^{3}$ Department of Biophysics, School of Medicine, Ardabil University of Medical Sciences, Ardabil 5618985991, Iran \\ ${ }^{4}$ Department of Chemistry, Faculty of Basic Sciences, University of Sistan and Baluchistan, Zahedan 9816745345, Iran
}

Correspondence should be addressed to Nowruz Najafzadeh; n.najafzade@arums.ac.ir

Received 24 March 2014; Revised 19 June 2014; Accepted 19 June 2014; Published 24 July 2014

Academic Editor: Gary S. Shaw

Copyright (C) 2014 Shahram Hadizadeh et al. This is an open access article distributed under the Creative Commons Attribution License, which permits unrestricted use, distribution, and reproduction in any medium, provided the original work is properly cited.

\begin{abstract}
As a part of a drug development program to discover novel therapeutic and more effective palladium (Pd) based anticancer drugs, a series of water-soluble Pd complexes have been synthesized by interaction between $\left[\mathrm{Pd}(\mathrm{phen})\left(\mathrm{H}_{2} \mathrm{O}\right)_{2}\left(\mathrm{NO}_{3}\right)_{2}\right]$ and alkylenebisdithiocarbamate(al-bis-dtc) disodium salts. This study was undertaken to examine the possible cytotoxic effect of three novel complexes $(0.125-64 \mu \mathrm{g} / \mathrm{mL})$ on human gastric carcinoma (AGS), esophageal squamous cell carcinoma (Kyse-30), and hepatocellular carcinoma (HepG2) cell lines. The cytotoxicity was examined using cell proliferation and acridine orange/ethidium bromide (AO/EB) assay. In order to examine the effects of new $\mathrm{Pd}(\mathrm{II})$ complexes on cell cycle status, we performed cell cycle analysis. The complexes were found to have completely lethal effects on the cell lines, and the half maximal inhibitory concentration (IC50) values obtained for the cell lines were much lower in comparison with cisplatin. We demonstrated that the three new Pd(II) complexes are able to induce G2/M phase arrest in AGS and HepG2; in addition, the Pd(II) complexes caused an S phase arrest in Kyse-30 cell line. Our results indicate that newly synthesized Pd(II) complexes may provide a novel class of chemopreventive compounds for anticancer therapy.
\end{abstract}

\section{Introduction}

Cancer is a major public health problem in the world and more patients are afflicted with gastrointestinal cancer [1]. According to GLOBOCAN 2008 [2], there are increased incidence rates of the esophageal [3], gastric $[4,5]$, colon $[6,7]$, and hepatic $[8,9]$ cancers. In the world, about 12.7 million cancer new cases and 7.6 million cancer deaths are estimated to have occurred [2]. A substantial proportion of the cancer morbidity could be prevented through early detection and treatments, which renders the quest for highly effective antineoplastic agents [6].

Cisplatin is one of the most successful anticancer compounds that have been used clinically for more than 40 years. It is commonly used to treat several human cancers such as testicular [10] and ovarian [11] cancers and also it is widely employed for treating bladder [12], cervical [13], head and neck [14], esophageal [15], and nonsmall cell lung [16] cancers.

The biological activity of cisplatin cytotoxicity involves the binding of the drug to DNA and non-DNA targets and inhibits transcription and DNA replication that finally leads to apoptosis, necrosis, or both of them. The main site of cisplatin attack to DNA is N7 atoms of guanine and adenine located in the major groove of the double helix [17]. Furthermore, DNA is not the only target for platinum(Pt) complexes, but many other cell components, including glutathione, methionine, and other S-containing biomolecules, can play this role [18-20]. Cisplatin resistance is a mechanism that includes decreased drug accumulation 
in cancer cells, inactivation by thiol containing biomolecules (glutathione), and enhanced repair of DNA damage [21-23].

Therapeutic use of cisplatin is limited due to its side effects such as ototoxicity, nausea, nephrotoxicity, and gastrointestinal and bone marrow toxicity as well as resistance to this drug. Recently, second-generation cisplatin analogues such as oxaliplatin, satraplatin (JM216), and LA-12 are described to have hepatotoxicity and nephrotoxicity milder than cisplatin [24]. Most anticancer compounds are ineffective in the treatment of malignant cancers; therefore, much attention has been focused to find more effective and less toxic complexes than the existing pharmaceuticals. Thus, attention has turned to other Pt group elements (Pd, ruthenium, iridium, rhodium, and osmium) and novel design strategy of metal complexes containing $\mathrm{N}$ and $\mathrm{S}$ donor ligands such as sodium diethyldithiocarbamate [25-29].

The Pd complexes display moderate activities; until now, none has yet been proven to be effective in patients. Recently, some new $\mathrm{Pd}$ (II) and P(II) complexes have been synthesized to combine anticancer activity and reduce toxic effects of cisplatin [30]. More recently, we have been studying some diimine $\mathrm{Pt}(\mathrm{II})$ and $\mathrm{Pd}(\mathrm{II})$ complexes of dithiocarbamate derivative as potential anticancer agents [31].

In the present work, three novel $\mathrm{Pd}(\mathrm{II})$ complexes with a dithiocarbamate(dtc) with the formulas (complex $1=\mu-1$, 3-propylene bis(dithiocarbamate) bis(1,10-phenanthroline $\mathrm{Pd}(\mathrm{II})$ ) nitrate), (complex $2=\mu-1$, 4-butylene bis(dithiocarbamate) bis(1,10-phenanthroline $\mathrm{Pd}(\mathrm{II})$ ) nitrate), and (complex $3=\mu-1,8$-octylene bis(dithiocarbamate) bis(1,10-phenanthroline $\mathrm{Pd}(\mathrm{II}))$ nitrate) have been synthesized and characterized. Previously, three $\operatorname{Pd}(\mathrm{II})$ complexes of $\mathrm{M}\left(2,2^{\prime}\right.$-bipyridine) (morpholine dithiocarbamate) $\mathrm{NO}_{3} \mathrm{Pd}(\mathrm{II})$ complexes, 1,10-phenanthroline hexyl dithiocarbamatopalladium (II) nitrate [32], and $\alpha$-diimine platinum(II) and $\mathrm{Pd}(\mathrm{II})$ dithiocarbamate complexes [31] have been synthesized and characterized by good anticancer activity. However, dithiocarbamate complexes of metals could be more interesting and they display cytotoxic properties [30]. Thus, in this study, we report the cytotoxicity of three palladium(II) complexes with dithiocarbamate ligands and the effect of hydrocarbon chain lengths (propylene, butylene, and octylene) in the structure of these complexes on the anticancer activity compared to cisplatin. The $\mathrm{Pd}(\mathrm{II})$ complexes are expected to bind DNA by intercalation [33], a mechanism different from that of interaction of cisplatin with DNA. Metal complexes that contain 1,10-phenanthroline have been known to have effective anticancer activity and also to be intercalated between the DNA base pairs [34-36].

Therefore, since several reports have represented the fact that $\mathrm{Pd}(\mathrm{II})$ complexes containing dithiol group have low side effects especially on the kidney [30] and based on the chemopreventive cytotoxicity of the three novel $\mathrm{Pd}(\mathrm{II})$ complexes and also chemosensitivity of esophageal, gastric, and liver cancers, we have decided to investigate the cytotoxicity of these complexes against gastrointestinal cancer cell lines of AGS, KYSE-30, and HepG2.

\section{Material and Methods}

2.1. Culture of Cell Lines. The cell lines used in this study included AGS, HepG2, and KYSE-30. The cell lines were obtained from the National Cell Bank of Iran (NCBI, Pasteur Institute of Iran, Tehran). The cells were maintained in RPMI 1640 (Cat. number 51800-035, Gibco, UK) medium supplemented with $10 \%$ heat-inactivated fetal bovine serum (FBS; Cat. number 10270-106, Gibco, UK), 2 mM L-glutamine, penicillin, and streptomycin. The cells were incubated at $37^{\circ} \mathrm{C}$ in a humidified atmosphere with $5 \% \mathrm{CO}_{2}$ until they reached $70-80 \%$ confluence. Then, the cells were detached by 0.25 $(\mathrm{w} / \mathrm{v})$ trypsin and $0.02(\mathrm{w} / \mathrm{v})$ ethylenediaminetetraacetic acid (EDTA) and were then plated in a 96-well for cytotoxicity assessment.

2.2. Chemicals. A water soluble series of newly synthesized $\mathrm{Pd}$ (II) complexes of formula [(phen) Pd ( $\mu$-al-bis-dtc) $\mathrm{Pd}$ (phen) $\left(\mathrm{NO}_{3}\right)_{2}$ (where alkylenebisdithiocarbamate, al-bis$\mathrm{dtc}=$ propylenebisdithiocarbamate (pn-bis-dtc, 1 ); butylenebisdithiocarbamate (bu-bis-dtc, 2); and octylenebisdithiocarbamate (oc-bis-dtc, 3 ) and phen = 1,10-phenanthroline) have been synthesized similar to the procedure outlined by Islami-Moghaddam et al. [25], by interaction between $\left[\mathrm{Pd}(\right.$ phen $\left.\left.)\left(\mathrm{H}_{2} \mathrm{O}\right)_{2}\right]\left(\mathrm{NO}_{3}\right)_{2}\right]$ and alkylenebisdithiocarbamate(al-bis-dtc)disodium salts. In these binuclear $\mathrm{Pd}(\mathrm{II})$ complexes, 1,10-phenanthroline (phen) acts as capping ligand and al-bis-dtc bridges the two Pd centers. Cisplatin was purchased from Merck (232120) and dissolved in dimethyl sulfoxide and added to the medium at $0.125-32 \mu \mathrm{g} / \mathrm{mL}$ concentrations

2.3. Cell Proliferation Assay. The effects of the $\mathrm{Pd}(\mathrm{II})$ complexes on cell viability were determined using 3-(4,5-dimethylthiazol-2-yl)-2,5-diphenyltetrazolium bromide (MTT) assay [37]. The AGS, Kyse-30, and HepG2 cells were plated at a density of $1 \times 10^{4}$ cells per well in $200 \mu \mathrm{L}$ medium and incubated overnight; next, the medium was exchanged with $0.125-64 \mu \mathrm{g} / \mathrm{mL}$ of three new $\mathrm{Pd}(\mathrm{II})$ complexes and indicated concentration of cisplatin in FBS-free RPMI 1640 medium. Afterwards, plates were incubated for 24 and $48 \mathrm{hrs}$. Then, the supernatant was removed and the MTT solution $(5 \mathrm{mg} / \mathrm{mL}$ in PBS, $20 \mu \mathrm{L}$, Sigma, M2128) was added to each well. Plates were incubated again for additional $4 \mathrm{hrs}$ at $37^{\circ} \mathrm{C}$ in a $5 \% \mathrm{CO}_{2}$. The supernatants were removed and DMSO $(200 \mu \mathrm{L})$ was added to each well. Plates were shaken for $10 \mathrm{~min}$ to dissolve the precipitate. The sample absorbance was read at $540 \mathrm{~nm}$ using a BioTek Synergy HT microplate reader (BioTek Instruments Inc., USA).

2.4. AO/EB Staining. AGS, Kyse-30, and HepG2 cell lines were seeded in six-well plates at a density of $1 \times 10^{3}$ cells per well and incubated overnight and then various concentrations $(0.125-64 \mu \mathrm{g} / \mathrm{mL})$ of the new $\mathrm{Pd}(\mathrm{II})$ complexes were added to each well and were incubated for $72 \mathrm{hrs}$. After the incubation, the plates were centrifuged for $5 \mathrm{~min}$ $(129 \mathrm{~g}, 1,000 \mathrm{rpm})$ at $4^{\circ} \mathrm{C}$ and were washed with phosphate buffer saline (PBS). The EB/AO dye mix $(100 \mu \mathrm{g} / \mathrm{mL}$ of $\mathrm{AO}$ 
TABle 1: IC50 $(\mu \mathrm{g})^{*}$ values of the complexes on AGS, Kyse-30, and HepG2 cell lines, as determined by MTT (24 and 48 hrs) assay. The cytotoxic activity of three novel Pd(II) complexes was significantly higher $(P<0.05)$ in comparison with cisplatin.

\begin{tabular}{|c|c|c|c|c|c|c|c|c|c|}
\hline \multirow{2}{*}{ Cell lines } & \multicolumn{3}{|c|}{ AGS } & \multicolumn{3}{|c|}{ Kyse-30 } & \multicolumn{3}{|c|}{ HepG2 } \\
\hline & $24 \mathrm{~h}$ & $48 \mathrm{~h}$ & Total IC50 & $24 \mathrm{~h}$ & $48 \mathrm{~h}$ & Total IC50 & $24 \mathrm{~h}$ & $48 \mathrm{~h}$ & Total IC50 \\
\hline Complex 1 & $0.74 \pm 0.11$ & $0.63 \pm 0.12$ & $0.68 \pm 0.12$ & $0.87 \pm 0.11$ & $0.89 \pm 0.25$ & $0.88 \pm 0.18$ & $1.00 \pm 0.01$ & $1.04 \pm 0.30$ & $1.02 \pm 0.16$ \\
\hline Complex 2 & $0.80 \pm 0.04$ & $0.75 \pm 0.22$ & $0.78 \pm 0.13$ & $1.02 \pm 0.20$ & $0.95 \pm 0.31$ & $0.98 \pm 0.26$ & $1.12 \pm 0.10$ & $1.23 \pm 0.20$ & $1.17 \pm 0.15$ \\
\hline Complex 3 & $1.48 \pm 0.46$ & $0.94 \pm 0.16$ & $1.2 \pm 0.31$ & $1.05 \pm 0.23$ & $1.06 \pm 0.22$ & $1.06 \pm 0.23$ & $1.30 \pm 0.15$ & $1.09 \pm 0.07$ & $1.19 \pm 0.11$ \\
\hline Cisplatin & $4.40 \pm 1.56$ & $3.76 \pm 0.3$ & $4.08 \pm 0.93$ & $1.79 \pm 0.30$ & $2.00 \pm 0.46$ & $1.9 \pm 0.38$ & $2.07 \pm 0.05$ & $2.09 \pm 0.15$ & $2.079 \pm 0.10$ \\
\hline
\end{tabular}

${ }^{*}$ Mean values \pm standard deviation from experiments.

and $100 \mu \mathrm{g} / \mathrm{mL}$ of EB) was prepared in PBS and $100 \mu \mathrm{L}$ was added to each well. Cells were viewed under an inverted fluorescence microscope (IX 71, OLYMPUS) and pictures were taken with a digital camera (DP 71, OLYMPUS). Tests were conducted in triplicate by counting a minimum of 100 total cells each by ImageJ software. Live cells were determined by the uptake of AO (green fluorescence). EB is only able to pass through the ruptured membrane of late apoptotic and necrotic cells. Live and dead apoptotic cells were identified by perinuclear condensation of chromatin stained by $\mathrm{AO}$ or $\mathrm{EB}$, respectively, and by the formation of the apoptotic bodies. Necrotic cells were identified by uniform labeling of the cells with EB (red fluorescence) [38-40].

2.5. Cell Cycle Analysis. Cell cycle phase alterations were determined by analytical DNA flow cytometry. Briefly, the cells were seeded in $25 \mathrm{~cm}^{2}$ flasks at a density of $1 \times 10^{6}$ cells. The cells were incubated for $24 \mathrm{hrs}$ with IC50 of the $\mathrm{Pd}(\mathrm{II})$ complexes and control was maintained in RPMI-1640 medium supplemented with $10 \%$ FBS. After the treatment, the DNA content and cell cycle distribution were determined by flow cytometry. The cells were washed with cold PBS twice and fixed in $70 \%$ ethanol at $4^{\circ} \mathrm{C}$ at least $4 \mathrm{hrs}$. The fixed cells were centrifuged $\left(300 \mathrm{~g}, 4^{\circ} \mathrm{C}, 5 \mathrm{~min}\right)$ and washed with cold PBS and then stained with 4,6-diamidino-2-phenylindole dihydrochloride (DAPi, $1 \mu \mathrm{g} / \mathrm{mL}$, Triton X-100 0.1\% v/v in $\mathrm{PBS}$ ) for $30 \mathrm{~min}$ at $37^{\circ} \mathrm{C}$ in the dark. The stained cells were then transferred to flow tubes by passing through a $30 \mu \mathrm{m}$ nylon mesh filters. Flow cytometric analysis was performed using a flow cytometer (Partec CyFlow Space, Germany). The distribution of cells in different cell cycle phases was analyzed using Partec FloMax software [41].

2.6. Statistical Analysis. Statistical analyses were performed using SPSS 16.0 software. Statistical differences among treated and control cells were determined by one-way ANOVA (analysis of variance) followed by Tukey post hoc comparison test and mean differences with $P<0.05$ were considered statistically significant. Dose response curves and IC50 values were generated using Sigma Plot10 (Systat Software, CA).

\section{Results}

3.1. Growth Inhibition Study. The anticancer effects of the Pd(II) complexes against AGS, HepG2, and KEYSE-30 cancer cell lines were assessed by MTT assay. Cell viability was determined using the MTT assay after treatment with the $\operatorname{Pd}(\mathrm{II})$ complexes for 24 and $48 \mathrm{hrs}$. It was found that the complexes exhibited cytotoxic effects in a dose dependent manner. According to the dose response curves, the complexes had strong growth inhibitory effects on AGS, Kyse-30, and HepG2 cells.

Furthermore, the IC50 values of the complexes were compared to cisplatin (Table 1). These values for $\mathrm{Pd}(\mathrm{II})$ complexes are much lower as compared to those achieved for cisplatin reported in this paper. The antitumor activity varied depending on the cell line type and concentration of the complexes. The difference between antitumor activities of the $\mathrm{Pd}(\mathrm{II})$ complexes is noticed and, in general, the activities were the same. The analysis of IC50 values showed that $\mathrm{Pd}(\mathrm{II})$ complexes 1 and 2 were more cytotoxic against AGS, Kyse-30, and HepG2 cells than complex 3 . The best cytotoxic effects were achieved by the Pd(II) complex $1(\mathrm{IC} 50=0.68)$ on AGS cells (Table 1 and Figure 3).

3.2. AO/EB Staining for Apoptotic Cells. Morphological characteristics of the new $\mathrm{Pd}(\mathrm{II})$ complexes induced cell death were determined by AO/EB staining shown in Figure 2. The results showed that, after incubation at $0.125-64 \mu \mathrm{g} / \mathrm{mL}$ of the three new Pd(II) complexes for $72 \mathrm{hrs}$, a series of morphological changes, including condensation and fragmentation of chromatin and nucleus and formation of apoptotic bodies, was observed which was the evidence of apoptosis. In contrast to the treated cells, viable cells exhibited normal and green nuclei appearances. After the incubation of AGS, HepG2, and KEYSE-30 cell lines with the tested compound, the decrease of cell viability in all experimental series was observed. It was correlated with the increase of concentration of the $\mathrm{Pd}(\mathrm{II})$ complexes.

3.3. Effects of the Pd Complexes on the Cell Cycle. Flow cytometric analysis demonstrated the growth inhibitory effects of the complexes on cell cycle progression. The cancer cell lines were treated with increasing concentrations of the $\mathrm{Pd}(\mathrm{II})$ complexes in complete medium and the effective dose was determined to be at the concentration close to IC50 values to obtain significant cell cycle arrest (Figure 4 ). The percentages of cells in G0/G1, S, and G2/M phase were calculated using Partec FloMax software and were shown in Table 2 and Figure 4. Flow cytometry analysis demonstrated that, with the IC50 values of the complexes, the population of AGS and 


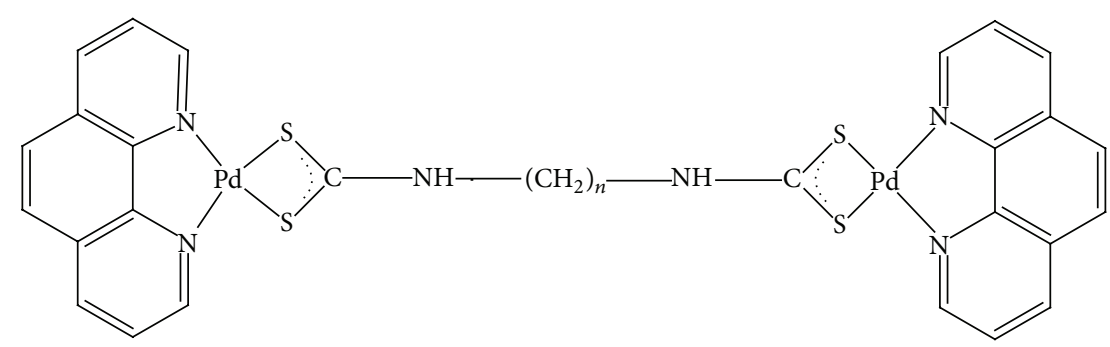

FIGURE 1: The schematic structure of Pd(II) complexes (complex 1: $n=3$, complex 2: $n=4$, and complex 3: $n=8$ ).

TABLE 2: The Pd(II) induced cell cycle arrest. The cell cycle progression blockage was seen in G2-M after 24 hrs of treatment with the IC50 of the Pd(II) complexes.

\begin{tabular}{lccccccccc}
\hline & \multicolumn{3}{c}{ AGS } & \multicolumn{3}{c}{ Kyse-30 } & \multicolumn{3}{c}{ HepG2 } \\
& G0-G1\% & S\% & G2M\% & G0-G1\% & S\% & G2M\% & G0-G1\% & S\% & G2M\% \\
\hline Control & $53.85 \pm 1.95$ & $21.27 \pm 3.50$ & $24.88 \pm 2.20$ & $54.39 \pm 1.32$ & $16.6 \pm 1.59$ & $29.01 \pm 1.83$ & $55.97 \pm 0.4795$ & $16.35 \pm 0.99$ & $27.68 \pm 1.86$ \\
Complex 1 & $50 \pm 1.44$ & $12.15 \pm 0.59$ & $37.84 \pm 1.66^{\mathrm{a}}$ & $53.01 \pm 3.48$ & $23.92 \pm 0.26^{\mathrm{a}}$ & $22.4 \pm 3.16$ & $52.04 \pm 3.06$ & $11.39 \pm 4.84$ & $36.57 \pm 2.76^{\mathrm{a}}$ \\
Complex 2 $51.24 \pm 4.65$ & $9.29 \pm 0.56$ & $39.47 \pm 4.1^{\mathrm{a}}$ & $49.98 \pm 1.68$ & $21.31 \pm 2.13^{\mathrm{a}}$ & $28.70 \pm 4.98$ & $47.41 \pm 4.2$ & $16.68 \pm 1.53$ & $35.90 \pm 0.97^{\mathrm{a}}$ \\
Complex 3 52.85 \pm 3.77 & $11.83 \pm 6.95$ & $35.31 \pm 4.16^{\mathrm{a}}$ & $47.96 \pm 7.65$ & $25.17 \pm 3.52^{\mathrm{a}}$ & $26.87 \pm 4.13$ & $46.64 \pm 4.64$ & $14.19 \pm 2.20$ & $39.18 \pm 3.15^{\mathrm{a}}$ \\
\hline
\end{tabular}

The data were pooled from three independent tests and were presented as mean \pm STDEV; ${ }^{\mathrm{a}}<0.05$.

HepG2 cells in the G2/M checkpoint was increased significantly with respect to controls. After $24 \mathrm{hrs}$, only $24.88 \%$ of untreated AGS cells were in G2/M phase, but $37.84 \%$ of $0.68 \mu \mathrm{g} / \mathrm{mL}$ complex $1,39.47 \%$ of $0.78 \mu \mathrm{g} / \mathrm{mL}$ complex 2 , and $35.31 \%$ of $0.94 \mu \mathrm{g} / \mathrm{mL}$ complex 3 treated cells and HepG2 $(P<0.05$ for $36.57 \%, 35.90 \%$, and 39.18 of complexes-1-3 treated cells with respect to $27.68 \%$ of untreated cells) cell lines were in G2/M phase, respectively. The Pd complexes caused an S phase arrest in Kyse-30 cell line (measured at $24 \mathrm{~h}$ after treatment), which is not expected since $\mathrm{Pd}(\mathrm{II})$ complex treatment leads to DNA damage in the G2-M phase of the cell cycle $(P<0.05$, for $23.92 \%, 21.31 \%$, and $25.17 \%$ of complexes$1-3$ treated cells, with respect to $16.6 \%$ of untreated cells, resp.) (Table 2 and Figure 4).

\section{Discussion}

Since the discovery of cisplatin, many new Pt and Pd complexes have been synthesized and evaluated for their possible cytotoxic activity. However, a few of them were recently approved and carboplatin and oxaliplatin are being used as an anticancer drug against several human cancers [21, 42]. Despite the common clinical use of chemotherapeutic agents, cancer recurrence results in the death of many patients due to resistance to chemotherapy [23]. Therefore, there have been many attempts to find complexes which might serve as less toxic and more effective anticancer drugs [43, 44]. In this study, we synthesized three novel Pd(II) complexes. The chemical characteristics of the three novel Pd complexes prompted us to test its potential anticancer activity in vitro. In fact, due to detoxicant properties of dithiocarbamate against heavy metal intoxication, it is possible that diethyldithiocarbamate reduced the toxicity of these three Pd complexes. In the present study, we have investigated the cytotoxic activity and mechanism of action of the three novel Pd(II) complexes on AGS, HepG2, and KYSE-30 cancer cell lines. We demonstrated that the new complexes likely behave in a cytotoxic manner towards the cancer cell lines. On the basis of the MTT it was shown that the three Pd(II) complexes exerted stronger cytotoxic influence on the cell line. In all cell types the IC50 values were lower when compared to cisplatin. All the cell lines were susceptible. Generally, at lower concentrations $(0.68-1.2 \mu \mathrm{g})$, the $\mathrm{Pd}$ (II) complexes induced similar levels of cell death. Therefore, fewer drugs are required to induce cancer cell death and thus can be tolerated by patients. Significantly, this study shows the importance of using a panel of cell lines and Pd(II) complexes. Taking this into account, we can conclude that the cytotoxic activity of three novel Pd(II) complexes may also be related to its geometric structure and size of the molecule (Figure 1).

These data are consistent with those obtained from other studies, which revealed that diimine $\mathrm{Pd}(\mathrm{II})$ complexes of alkyldithiocarbamate derivatives had anticancer properties on hepatocellular carcinoma, human ovarian carcinoma, and human lung adenocarcinoma cancer cells [43].

Recently, different complexes of Pd were synthesized and their cytotoxic effects were evaluated by our group. In our previous study, we reported the synthesis and cytotoxicity of two new metal complexes, namely, $2,2^{\prime}$ bipyridinebutyldithiocarbamatoplatinum(II) and Pd(II). We demonstrated that these compounds have strong antitumor activity against chronic myelogenous leukemia cell line, K562, compared to cisplatin [44]. In another study, Mansouri-Torshizi et al. revealed that the $\alpha$-diimine Pt(II) and $\mathrm{Pd}(\mathrm{II})$ dithiocarbamate complexes had anticancer properties against K562 and the obtained IC50 values for Pd(II) (IC50 $=0.007 \mathrm{mM}$,) complexes were lower than those for cisplatin $($ IC50 $=0.154 \mathrm{mM})$. Furthermore, the analysis of the interaction of these novel compounds with CT-DNA suggests that they can intercalate in DNA [27]. In another 

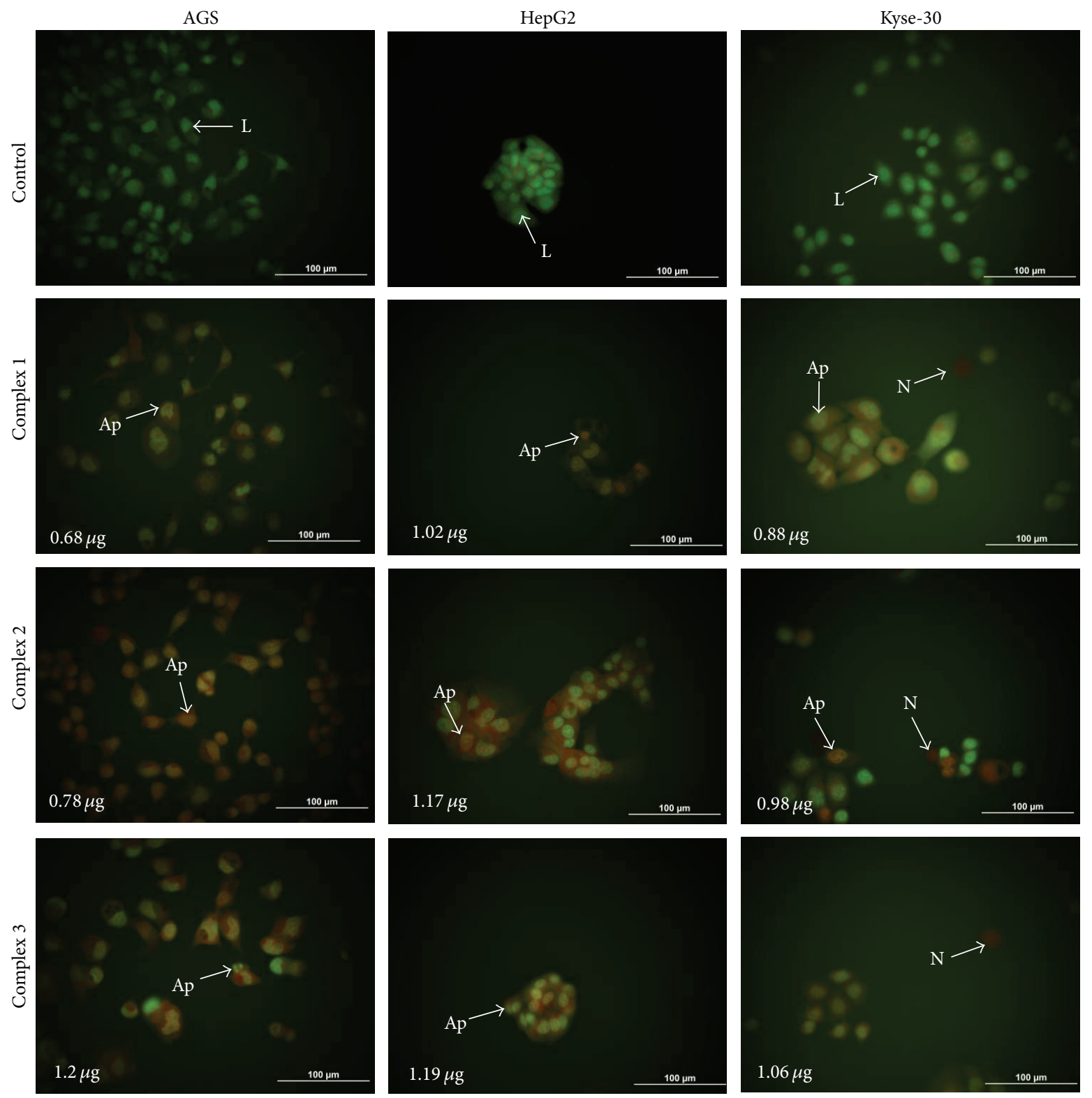

FIGURE 2: Photomicrographs of AO/EB-stained control AGS, Kyse-30, and HepG2 cells and the cells treated with IC50 of the Pd complexes (13) for 72 hrs. Representative photomicrographs show live, apoptotic, and necrotic cells treated with the Pd complexes. L: Live; Ap: apoptotic; N: Necrotic.

study, Ulukaya et al. used new Pd complex ([PdCl(terpy)] $(\mathrm{sac}) \cdot 4 \mathrm{H}_{2} \mathrm{O},\left(\mathrm{sac}=\right.$ saccharinate, and terpy $=2,2^{\prime}: 6^{\prime}, 2^{\prime \prime}$ terpyridine) against six prostate cancer cell lines, cancer stem cells, and primary culture. They found that the Pd complexes cause DNA damage, cell death, and autophagy [45].

The pattern of cell death was studied by AO/EB. Measurement of $\mathrm{AO} / \mathrm{EB}$-stained nuclei showed that the color of the nuclei of cells treated with the three Pd(II) complexes was orange or red. The changes in the color of nuclear chromatin were accompanied by chromatin condensation and fragmentation, which was also observed after $\operatorname{Pd}(\mathrm{II})$ treatment. The results demonstrated that the new complexes apply cytotoxic effect via an apoptotic pathway.
The mechanism for the inhibition was further investigated with cell cycle analysis. Following treatment with the Pd complex, the AGS and HepG2 cell lines showed an increase in cells with G2-M DNA content, except in Kyse-30 cells where they appear to be arrested in $S$ phase. Overall, it appears that the Pd complex had different effects on the cell cycle status in various cell lines. In the study of Mukherjee et al. using Pd complexes with a hydrazone ligand, prostate cancer (PC-3) cell growth was inhibited at G2/M phase and apoptosis induced by activation of caspase3 [46]. Metal complexes containing 1,10-phenanthroline are known to produce DNA adducts by intercalation, which inhibit replication and transcription of DNA [33]. 

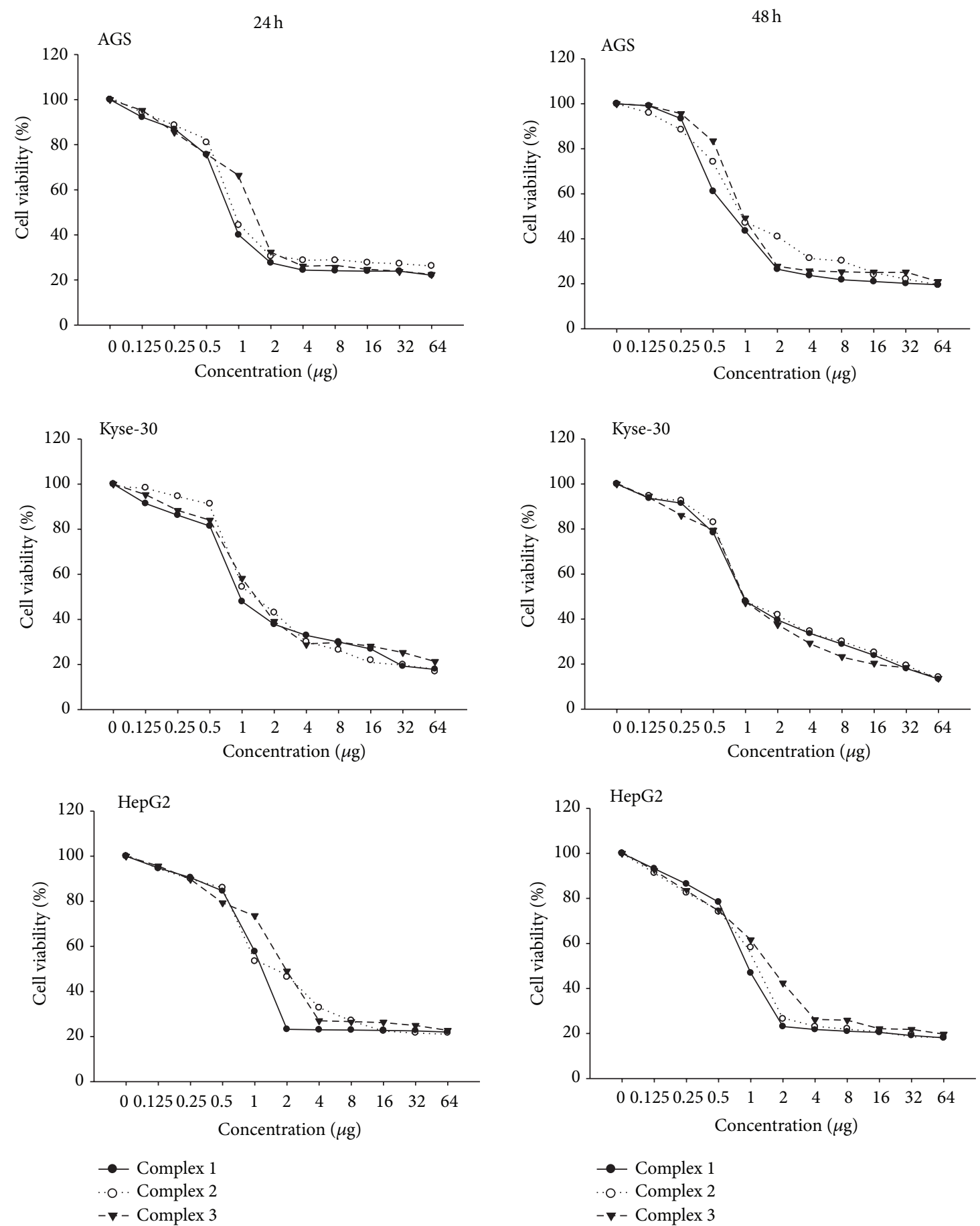

FIGURE 3: Representative graphs of AGS, Kyse-30, and HepG2 cells survival after 24 and 48 hrs of cell growth in the presence of the three Pd(II) complexes.

\section{Conclusion}

In conclusion, the new $\mathrm{Pd}(\mathrm{II})$ complexes are more efficient in their action on gastric, hepatic, and esophageal cancer cell lines than cisplatin. Importantly, they also successfully inhibited the viability of cancer cells at lower concentrations, implying that these Pd(II) complexes may be used for treatment of cancer. Although we have shown that he novel Pd complexes mediated cell cycle arrest at G2/M and
$S$ phases. Finally, the understanding of in vivo effects of three new complexes needs to be investigated further, especially with animal tumor models to confirm its anticancer and chemotherapeutic activity in vivo.

\section{Conflict of Interests}

The authors declare that there is no conflict of interests regarding the publication of this paper. 

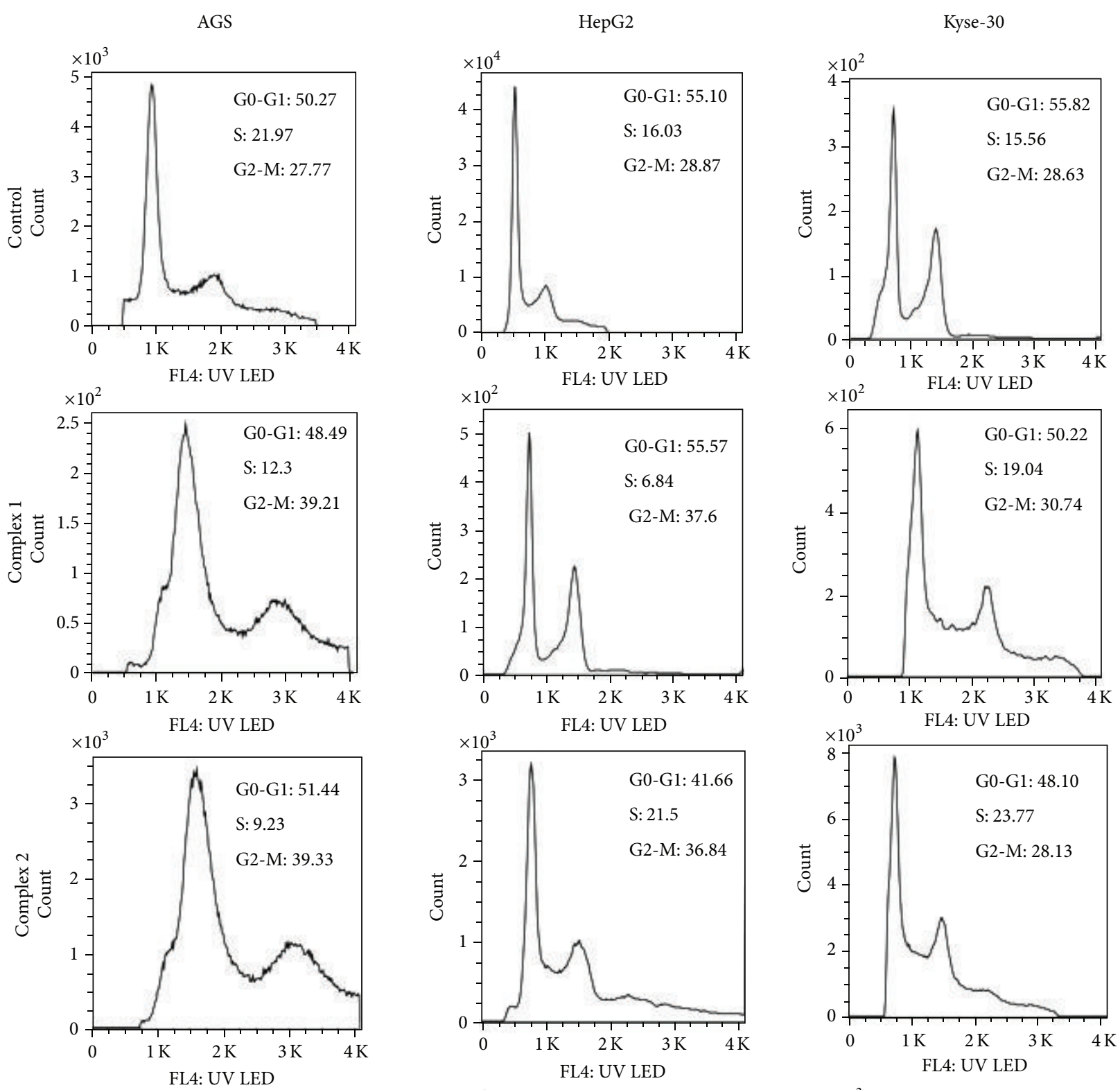

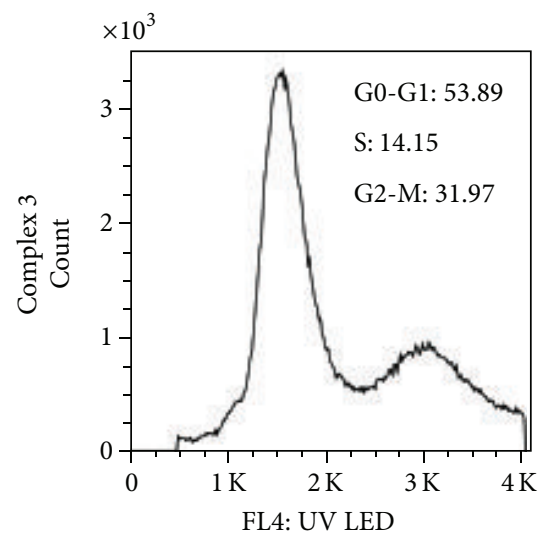

(a)

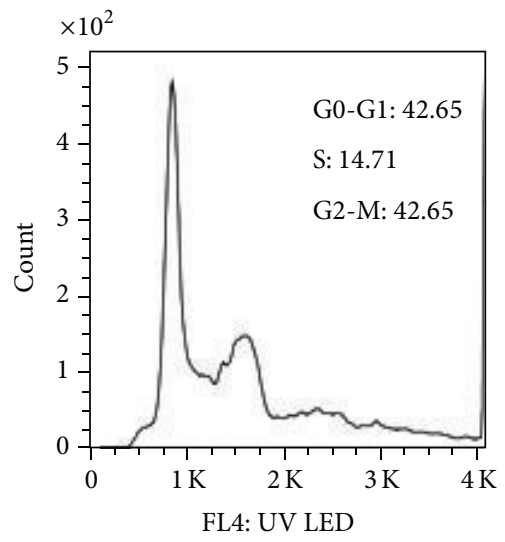

(b)

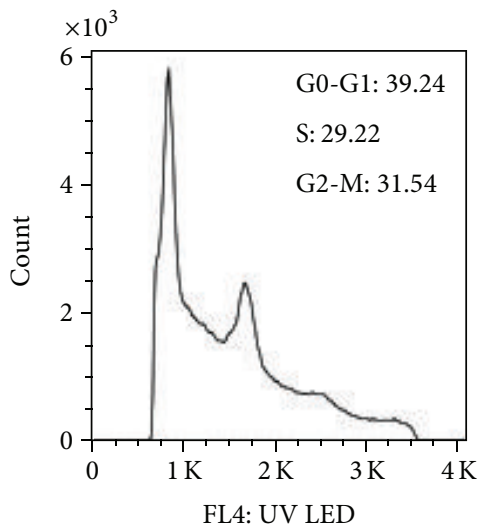

(c)

FIgURE 4: Palladium complex induced cell cycle arrest. AGS, Kyse-30, and HepG2 cell lines were incubated with IC50 of the Pd complexes. After the incubation for $24 \mathrm{hrs}$, the cells were harvested and stained with DAPi, and DNA content was assessed by flow cytometry. The percentage of cells in each phase was plotted as a function of IC50 of the Pd complexes. The progression of AGS (a) and HepG2 (b) cell cycle was blocked in G2-M when treated with IC50 of three Pd complexes; hence, they stop Kyse-30 cell cycle progression in the S phase (c). 


\section{Authors' Contribution}

Nowruz Najafzadeh, Mohammad Mazani, Shahram Hadizadeh, Hassan Mansouri-Torshizi, Mojtaba Amani, and Ali Niapour conceived and designed the experiment. Nowruz Najafzadeh and Shahram Hadizadeh performed the experiment. Nowruz Najafzadeh, Shahram Hadizadeh, Mohammad Mazani, and Ali Niapour analyzed the data. Nowruz Najafzadeh, Shahram Hadizadeh, and Hassan Mansouri-Torshizi contributed reagents/materials/analysis tools. Nowruz Najafzadeh, Shahram Hadizadeh, and Ali Niapour wrote the paper.

\section{Acknowledgments}

The authors would like to thank S. Bohlooli for assistance in supplying AGS cell line. They would like to thank N. Jafari for flow cytometry protocol. This work was supported by a Thesis Grant for Master of Science in Clinical Chemistry from Ardabil University of Medical Sciences.

\section{References}

[1] F. Kamangar, G. M. Dores, and W. F. Anderson, "Patterns of cancer incidence, mortality, and prevalence across five continents: defining priorities to reduce cancer disparities in different geographic regions of the world," Journal of Clinical Oncology, vol. 24, no. 14, pp. 2137-2150, 2006.

[2] A. Jemal, F. Bray, M. M. Center, J. Ferlay, E. Ward, and D. Forman, "Global cancer statistics," CA Cancer Journal for Clinicians, vol. 61, no. 2, pp. 69-90, 2011.

[3] F. Ghasemi-Kebria, G. Roshandel, S. Semnani et al., "Marked increase in the incidence rate of esophageal adenocarcinoma in a high-risk area for esophageal cancer," Archives of Iranian Medicine, vol. 16, no. 6, pp. 320-323, 2013.

[4] W. J. Blot, S. S. Devesa, R. W. Kneller, and J. F. Fraumeni Jr., "Rising incidence of adenocarcinoma of the esophagus and gastric cardia," The Journal of the American Medical Association, vol. 265 , no. 10, pp. 1287-1289, 1991.

[5] L. Yang, "Incidence and mortality of gastric cancer in China," World Journal of Gastroenterology, vol. 12, no. 1, pp. 17-20, 2006.

[6] J. Ferlay, E. Steliarova-Foucher, J. Lortet-Tieulent et al., “Cancer incidence and mortality patterns in Europe: estimates for 40 countries in 2012," European Journal of Cancer, vol. 49, no. 6, pp. 1374-1403, 2013.

[7] R. E. Schoen, P. F. Pinsky, J. L. Weissfeld et al., "Colorectalcancer incidence and mortality with screening flexible sigmoidoscopy," The New England Journal of Medicine, vol. 366, no. 25, pp. 2345-2357, 2012.

[8] F. X. Bosch, J. Ribes, M. Díaz, and R. Cléries, "Primary liver cancer: worldwide incidence and trends," Gastroenterology, vol. 127, supplement 1, no. 5, pp. S5-S16, 2004.

[9] A. Jemal, E. P. Simard, J. Xu, J. Ma, and R. N. Anderson, "Selected cancers with increasing mortality rates by educational attainment in 26 states in the United States, 1993-2007," Cancer Causes \& Control, vol. 24, no. 3, pp. 559-565, 2013.

[10] A. M. Burger, J. A. Double, and D. R. Newell, "Inhibition of telomerase activity by cisplatin in human testicular cancer cells," European Journal of Cancer, vol. 33, no. 4, pp. 638-644, 1997.
[11] D. K. Armstrong, B. Bundy, L. Wenzel et al., "Intraperitoneal cisplatin and paclitaxel in ovarian cancer," The New England Journal of Medicine, vol. 354, no. 1, pp. 34-43, 2006.

[12] E. G. Konstantakou, G. E. Voutsinas, P. K. Karkoulis, G. Aravantinos, L. H. Margaritis, and D. J. Stravopodis, "Human bladder cancer cells undergo cisplatin-induced apoptosis that is associated with p53-dependent and p53-independent responses," International Journal of Oncology, vol. 35, no. 2, pp. 401-416, 2009.

[13] P. G. Rose, B. N. Bundy, E. B. Watkins et al., "Concurrent cisplatin-based radiotherapy and chemotherapy for locally advanced cervical cancer," The New England Journal of Medicine, vol. 340, no. 15, pp. 1144-1153, 1999.

[14] M. R. Posner, D. M. Hershock, C. R. Blajman et al., "Cisplatin and fluorouracil alone or with docetaxel in head and neck cancer," The New England Journal of Medicine, vol. 357, no. 17, pp. 1705-1715, 2007.

[15] M. S. Kies, S. T. Rosen, T.-K. Tsang et al., "Cisplatin and 5fluorouracil in the primary management of squamous esophageal cancer," Cancer, vol. 60, no. 9, pp. 2156-2160, 1987.

[16] G. Giaccone, R. S. Herbst, C. Manegold et al., "Gefitinib in combination with gemcitabine and cisplatin in advanced nonsmall-cell lung cancer: a phase III trial-INTACT 1," Journal of Clinical Oncology, vol. 22, no. 5, pp. 777-784, 2004.

[17] D. Payet, F. Gaucheron, M. Sip, and M. Leng, "Instability of the monofunctional adducts in cis- $\left[\mathrm{Pt}\left(\mathrm{NH}_{3}\right)_{2}\left(\mathrm{~N}_{7}-\mathrm{N}\right.\right.$-methyl2-diazapyrenium)Cl ${ }^{2+}$;-modified DNA: rates of cross-linking reactions in cis-platinum-modified DNA," Nucleic Acids Research, vol. 21, no. 25, pp. 5846-5851, 1993.

[18] A. Divsalar, A. A. Saboury, L. Ahadi, E. Zemanatiyar, and H. Mansouri-Torshizi, "Investigation of effects of newly synthesized $\mathrm{Pt}(\mathrm{II})$ complex against human serum albumin and leukemia cell line of K562," BMB Reports, vol. 43, no. 11, pp. 766-771, 2010.

[19] J. Reedijk, "The mechanism of action of platinum anti-tumor drugs," Pure and Applied Chemistry, vol. 59, no. 2, pp. 181-192, 1987.

[20] X. Wang and Z. Guo, "The role of sulfur in platinum anticancer chemotherapy," Anti-Cancer Agents in Medicinal Chemistry, vol. 7, no. 1, pp. 19-34, 2007.

[21] V. Cepeda, M. A. Fuertes, J. Castilla, C. Alonso, C. Quevedo, and J. M. Pérez, "Biochemical mechanisms of cisplatin cytotoxicity," Anti-Cancer Agents in Medicinal Chemistry, vol. 7, no. 1, pp. 318, 2007.

[22] M. Ohmichi, J. Hayakawa, K. Tasaka, H. Kurachi, and Y. Murata, "Mechanisms of platinum drug resistance," Trends in Pharmacological Sciences, vol. 26, no. 3, pp. 113-116, 2005.

[23] C. A. Rabik and M. E. Dolan, "Molecular mechanisms of resistance and toxicity associated with platinating agents," Cancer Treatment Reviews, vol. 33, no. 1, pp. 9-23, 2007.

[24] V. Foltinová, L. S. Šindlerová, V. Horváth et al., "Mechanisms of effects of platinum (II) and (IV) complexes. Comparison of cisplatin and oxaliplatin with satraplatin and LA-12, new Pt (IV)-based drugs. A Minireview," Scripta Medica (BRNO), vol. 81, pp. 105-116, 2008.

[25] M. Islami-Moghaddam, H. Mansouri-Torshizi, A. Divsalar, and A. A. Saboury, "Synthesis, characterization, cytotoxic and DNA binding studies of diimine Platinum(II) and Palladium(II) complexes of short hydrocarbon chain ethyldithiocarbamate ligand," Journal of the Iranian Chemical Society, vol. 6, no. 3, pp. 552-569, 2009. 
[26] H. Mansouri-Torshizi, M. I-Moghaddam, A. Divsalar, and A. Saboury, "2,2I-Bipyridinebutyldithiocarbamatoplatinum(II) and palladium(II) complexes: synthesis, characterization, cytotoxicity, and rich DNA-binding studies," Bioorganic and Medicinal Chemistry, vol. 16, no. 21, pp. 9616-9625, 2008.

[27] H. Mansouri-Torshizi, M. I. Moghaddam, A. Divsalar, and A. A. Saboury, "Diimine platinum(II) and palladium(II) complexes of dithiocarbamate derivative as potential antitumor agents: synthesis, characterization, cytotoxicity, and detail DNA-binding studies," Journal of Biomolecular Structure and Dynamics, vol. 26, no. 5, pp. 575-586, 2009.

[28] M. Saeidifar, H. Mansouri-Torshizi, Y. Palizdar, A. Divsalar, and A. A. Saboury, "Synthesis, characterization, and cytotoxicity studies of a novel palladium(II) complex and evaluation of DNA-binding aspects," Nucleosides, Nucleotides and Nucleic Acids, vol. 32, no. 7, pp. 366-388, 2013.

[29] A. Vekris, D. Meynard, M. C. Haaz, M. Bayssas, J. Bonnet, and J. Robert, "Molecular determinants of the cytotoxicity of platinum compounds: the contribution of in silico research," Cancer Research, vol. 64, no. 1, pp. 356-362, 2004.

[30] A. Trevisan, C. Marzano, P. Cristofori, M. Borella Venturini, L. Giovagnini, and D. Fregona, "Synthesis of a palladium(II)dithiocarbamate complex: Biological assay and nephrotoxicity in rats," Archives of Toxicology, vol. 76, no. 5-6, pp. 262-268, 2002.

[31] H. Mansouri-Torshizi, M. Saeidifar, F. Khosravi, A. Divsalar, A. A. Saboury, and F. Hassani, "DNA binding and antitumor activity of $\alpha$-diimineplatinum(II) and palladium(II) dithiocarbamate complexes," Bioinorganic Chemistry and Applications, vol. 2011, Article ID 394506, 11 pages, 2011.

[32] H. Mansouri-Torshizi, M. Saeidifar, A. Divsalar, and A. A. Saboury, "Study on interaction of DNA from calf thymus with 1,10- phenanthrolinehexyldithiocarbamatopalladium(II) nitrate as potential antitumor agent," Journal of Biomolecular Structure and Dynamics, vol. 28, no. 5, pp. 805-814, 2011.

[33] H. Mansouri-Torshizi, M. Saeidifar, A. Divsalar, and A. A. Saboury, "Interaction studies between a 1,10-phenanthroline adduct of palladium(II) dithiocarbamate anti-tumor complex and calf thymus DNA. A synthesis spectral and in-vitro study," Spectrochimica Acta A: Molecular and Biomolecular Spectroscopy, vol. 77, no. 1, pp. 312-318, 2010.

[34] K. E. Erkkila, D. T. Odom, and J. K. Barton, "Recognition and reaction of metallointercalators with DNA," Chemical Reviews, vol. 99, no. 9, pp. 2777-2795, 1999.

[35] M. H. Werner, A. M. Gronenborn, and G. M. Clore, "Intercalation, DNA kinking, and the control of transcription," Science, vol. 271, no. 5250, pp. 778-784, 1996.

[36] G. Zhao, H. Sun, H. Lin, S. Zhu, X. Su, and Y. Chen, "Palladium(II) complexes with $\mathrm{N}, \mathrm{N}^{\prime}$-dialkyl-1,10-phenanthroline2,9- dimathanamine: synthesis, characterization and cytotoxic activity," Journal of Inorganic Biochemistry, vol. 72, no. 3-4, pp. 173-177, 1998.

[37] T. Mosmann, "Rapid colorimetric assay for cellular growth and survival: application to proliferation and cytotoxicity assays," Journal of Immunological Methods, vol. 65, no. 1-2, pp. 55-63, 1983.

[38] F. Attari, H. Sepehri, L. Delphi, and B. Goliaei, "Apoptotic and necrotic effects of pectic acid on rat pituitary GH3/B6 tumor cells," Iranian Biomedical Journal, vol. 13, no. 4, pp. 229-236, 2009.

[39] D. Baskić, S. Popović, P. Ristić, and N. N. Arsenijević, "Analysis of cycloheximide-induced apoptosis in human leukocytes:
Fluorescence microscopy using annexin V/propidium iodide versus acridin orange/ethidium bromide," Cell Biology International, vol. 30, no. 11, pp. 924-932, 2006.

[40] D. Ribble, N. B. Goldstein, D. A. Norris, and Y. G. Shellman, "A simple technique for quantifying apoptosis in 96-well plates," BMC Biotechnology, vol. 5, no. article 12, 2005.

[41] Y. Dobashi, T. Takehana, and A. Ooi, "Perspectives on cancer therapy: cell cycle blockers and perturbators," Current Medicinal Chemistry, vol. 10, no. 23, pp. 2549-2558, 2003.

[42] A. Vekris, D. Meynard, M. Haaz, M. Bayssas, J. Bonnet, and J. Robert, "Molecular determinants of the cytotoxicity of platinum compounds: the contribution of in silico research," Cancer Research, vol. 64, no. 1, pp. 356-362, 2004.

[43] N. Aryanpour, H. Mansouri-Torshizi, M. Nakhjavan, and F. H. Shirazi, "Cytotoxicity of diimine palladium (II) complexes of alkyldithiocarbamate derivatives on human lung, ovary and liver cells," Iranian Journal of Pharmaceutical Research, vol. 11, no. 2, pp. 689-695, 2012.

[44] H. Mansouri-Torshizi, M. I-Moghaddam, A. Divsalar, and A.A. Saboury, "2,2I-Bipyridinebutyldithiocarbamatoplatinum(II) and palladium(II) complexes: Synthesis, characterization, cytotoxicity, and rich DNA-binding studies," Bioorganic and Medicinal Chemistry, vol. 16, no. 21, pp. 9616-9625, 2008.

[45] E. Ulukaya, F. M. Frame, B. Cevatemre et al., "Differential cytotoxic activity of a novel palladium-based compound on prostate cell lines, primary prostate epithelial cells and prostate stem cells," PLoS ONE, vol. 8, no. 5, Article ID e64278, 2013.

[46] S. Mukherjee, S. Chowdhury, A. P. Chattapadhyay, and A. Bhattacharya, "Spectroscopic, cytotoxic and DFT studies of a luminescent palladium(II) complex of a hydrazone ligand that induces apoptosis in human prostate cancer cells," Inorganica Chimica Acta, vol. 373, no. 1, pp. 40-46, 2011. 

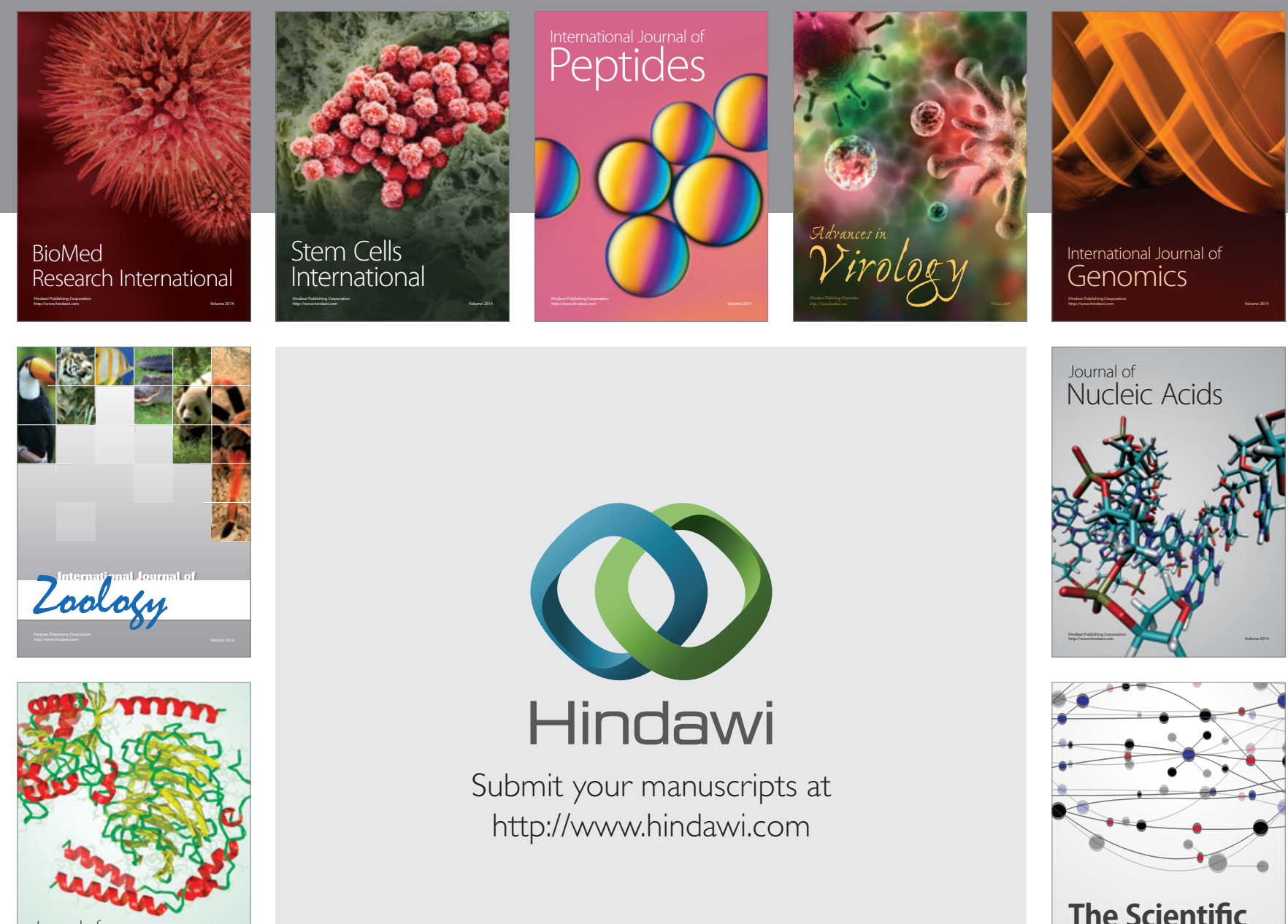

Submit your manuscripts at

http://www.hindawi.com

Journal of
Signal Transduction
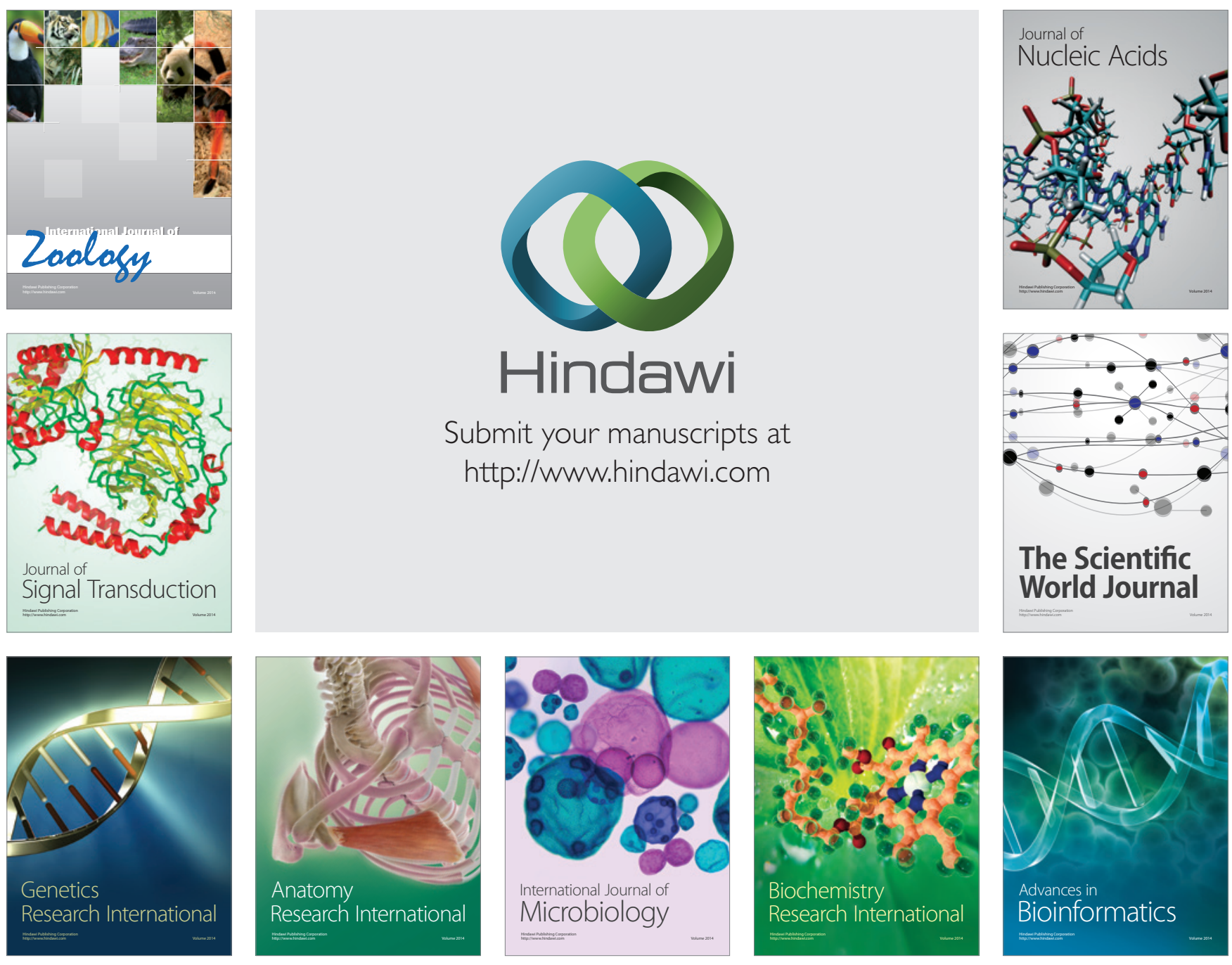

The Scientific World Journal
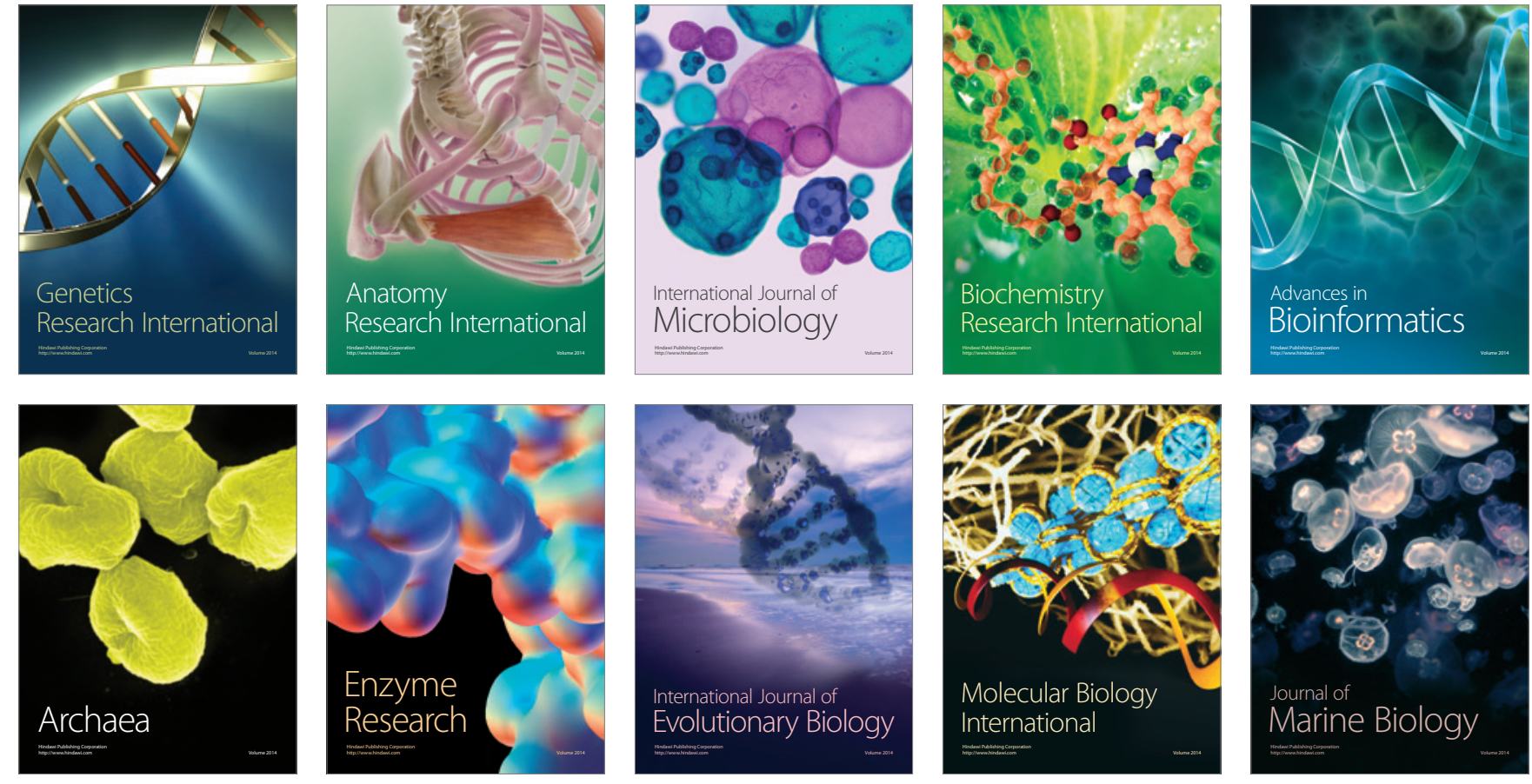